\title{
Glyphosate Effect on Nitrogen Fixation and Metabolization in RR Soybean
}

\author{
Nayane Cristina Pires Bomfim ${ }^{1}$, Beatriz Gonçalves Pereira Costa ${ }^{1}$, Lucas Anjos Souza ${ }^{2}$, Gilberto Costa Justino ${ }^{3}$, \\ Leandro Ferreira Aguiar ${ }^{4} \&$ Liliane Santos Camargos ${ }^{1}$ \\ ${ }^{1}$ Universidade Estadual Paulista (UNESP), Faculdade de Engenharia, Departamento de Biologia e Zootecnia, \\ Ilha Solteira, SP, Brazil \\ ${ }^{2}$ Instituto Federal Goiano, Campus Rio Verde, Rio Verde, GO, Brazil \\ ${ }^{3}$ Universidade Federal de Alagoas, Instituto de Ciências Biológicas e da Saúde, Setor de Botânica, Maceió, AL, \\ Brazil \\ ${ }^{4}$ Universidade Federal de Mato Grosso do Sul, Campus de Três Lagoas, Três Lagoas, MS, Brazil \\ Correspondence: Liliane Santos Camargos, Universidade Estadual Paulista (UNESP), Faculdade de Engenharia, \\ Departamento de Biologia e Zootecnia, Ilha Solteira, SP, Brazil. Email: camargos@bio.feis.unesp.br
}

Received: July 10, 2017

Accepted: August 12, $2017 \quad$ Online Published: September 15, 2017

doi:10.5539/jas.v9n10p114

URL: https://doi.org/10.5539/jas.v9n10p114

\begin{abstract}
To evaluate under controlled temperature conditions, nutrition and water supply, the influence of glyphosate on nitrogen fixation capacity in Roundup Ready (RR) soybean, BRS Valiosa Roundup Ready. Commercially available seeds were sown in pots containing vermiculite and washed sand (1:1) and after germination, the seeds were inoculated with Bradyrhizobium sp. and kept in nutrient solution without nitrogen, in greenhouse, with temperature control to $27{ }^{\circ} \mathrm{C}$ without photoperiod control, at UNESP, Ilha Solteira, SP. At the vegetative stage, glyphosate was applied at a concentration of $1.8 \mathrm{mg}$ glyphosate/plant once a week. There were two harvests: after 15-21 days after herbicide application, and at reproductive stage. The chlorophyll content in leaves was analyzed and the organs were separated (leaves, roots and nodules) for extraction and quantitation of nitrogenous compounds, in addition to the enzyme allantoinase activity analysis (in vitro) and nitrogenase activity (in vivo). Nodules were counted and weighted. Means were compared by 5\% Tukey's test. It was observed that the application of glyphosate in RR soybeans moderately affected $\mathrm{N}$ fixation and assimilation. There were no drastic metabolic changes for the aminoacids, proteins, chlorophylls and ureides in RR soybean treated with glyphosate.
\end{abstract}

Keywords: N-fixation, amino acids, chlorophyll, ureides

\section{Introduction}

Soybean (Glycine max (L.) Merril) is one of the most important crop, and its cultivation is increasing over the years. Biotechnological advances resulted in the development of new soybean cultivars, some genetically modified, such Roundup Ready soybean, which is resistant to glyphosate, thus allowing the use of this broad-spectrum herbicide during soybean cultivation (Dvoranen et al., 2008).

In glyphosate resistant soybean, the resistance was achieved by the insertion of the AroA gene from Agrobacterium sp., strain CP4, that codify a variant of the enzyme EPSPs (CP4EPSPs), that is specially tolerant to the inhibition by glyphosate (Padgette et al., 1995). Under glyphosate treatment, these transgenic plants are not affected due to the non-inhibition of CP4EPSPs (Santos et al., 2007), therefore, the weeds are controlled without affecting soybean production.

Glyphosate in a salt of N-(phosphonomethil)-glycine, it is an aminophosphonate analogous to the natural amino acid glycine, that inhibit the enzyme EPSPs. Shikimate pathway is absent in animals, but it is essential for the synthesis of aromatic amino acids in plants, fungi and bacteria (Hinchee et al., 1993). It is estimate that more than $20 \%$ of total carbon fixed by photosynthesis, pass through this pathway to the synthesis of aromatic amino acids, as reported by Sizenando-Filho et al. (2013).

On the other hand, glyphosate may affect biological nitrogen fixation (BNF) due to decrease in nickel content, and this micronutrient is essential for symbiotic microorganisms that perform BNF. So, once $\mathrm{N}$ fixing bacteria 
from nodules do not have the tolerant enzyme (CP4EPSPs) BFN may be impaired by glyphosate (Santos et al., 2004; María et al., 2006; Zablotowicz \& Reddy, 2007).

Despite its great economic importance, there is no published data on $\mathrm{N}$ metabolism, throughout the plant cycle, in response to glyphosate. Therefore, this work aimed to assess the influence of glyphosate on nitrogen fixation and metabolism in RR soybean, cultivar BRS Valiosa RR, under controlled conditions of temperature, nutrition and water supply.

\section{Material and Methods}

\subsection{Experimental Design}

The experiment was carried out in greenhouse, in completely randomized design, using commercially available RR soybean seeds, cultivar BRS Valiosa. It was composed of two treatments, with glyphosate application and without glyphosate. For each treatment, it was prepared 40 pots with 2 plants per pot.

After germination, the seedlings were transferred to $4 \mathrm{~L}$ pots containing vermiculite and sand $(1: 1)$ and, in these pots, Bradyrhizobium sp. was inoculated. During the experiment, plants received $100 \mathrm{~mL}$ of Hoagland \& Arnon (1938) nutritive solution without nitrogen, in order to keep nodules functioning.

The total amount of herbicide, Roundup Ready ${ }^{\circledR}$, sprayed was of $1.8 \mathrm{mg} \mathrm{plant}^{-1}$, by means of a manual water sprayer, once a week between the vegetative stages V2 and V4.

After 15-21 days, it was carried out the first harvest at vegetative stage and the second harvest was performed at reproductive stage. It was randomly chosen four repetitions of each treatment in each harvest.

\subsection{Growth and Biochemical Analysis}

Plants were harvested and separated in leaves, roots and nodules. These organs were stored at $-80^{\circ} \mathrm{C}$ biofreezer for further nitrogenous compounds extraction according to Bieleski and Turner (1966). Total soluble protein was also extracted from these materials by using $0.1 \mathrm{~N} \mathrm{NaOH}$ solution.

Chlorophyll quantitation was carried out according to Hiscox and Israelstam (1979). Amino acids, total soluble protein, total ureides, allantoin and allantoic acid quantitation was carried according described in Ferreira et al. (2016).

Nitrogenase enzyme activity was determined using the N-Fixation Package (Qubit Systems-Canada) system by quantifying the amount of $\mathrm{H}_{2}$ released. The allantoinase activity was determined according to Gomes was used; Sodek (1984) by measuring the amount of allantoic acid produced.

The data were subjected to analysis of variance and the data were compared by Tukey's test at $5 \%$.

\section{Results}

During the life cycle, amino acids concentration in roots was higher in vegetative stage than in reproductive, while in leaves the response was the opposite, as can be checked in (Table 1), remembering that in both stages we had herbicide untreated and treated plants. Protein accumulation did not vary between organs during different stages and herbicide application (Table 1). However, when analyzing the unfolding of the interaction between treatment and stage of development of the plant, the higher protein concentration, in roots, was found at reproductive stage with glyphosate application (Table 5). 
Table 1. Total soluble amino acid $\left(\mu \mathrm{mol} \mathrm{g} \mathrm{g}^{-1} \mathrm{DW}\right)$, protein and chlorophyll $\left(\mathrm{mg} \mathrm{g}^{-1} \mathrm{DW}\right)$ in nodules, roots and leaves in RR soybean plants, cultivar BRS Valiosa, under glyphosate $\left(1.8 \mathrm{mg} \mathrm{plant}^{-1}\right)$ during vegetative and reproductive stages

\begin{tabular}{|c|c|c|c|c|c|c|c|c|c|}
\hline Treatments & AAS-L & AAS-R $^{(1)}$ & AAS-N $^{(1)}$ & PRO-L ${ }^{(1)}$ & PRO-R & PRO-N ${ }^{(1)}$ & CLO- $a^{(1)}$ & CLO- $b^{(1)}$ & CLO-T \\
\hline \multicolumn{10}{|l|}{ Stage-S } \\
\hline Vegetative & $11.78 \mathrm{~b}$ & $3.42 \mathrm{a}$ & $3.88 \mathrm{a}$ & $0.92 \mathrm{a}$ & $3.26 \mathrm{a}$ & $1.92 \mathrm{a}$ & $2.26 \mathrm{a}$ & $2.40 \mathrm{a}$ & $10.70 \mathrm{a}$ \\
\hline Reproductive & $21.07 \mathrm{a}$ & $1.50 \mathrm{~b}$ & $3.33 \mathrm{a}$ & $1.02 \mathrm{a}$ & $3.61 \mathrm{a}$ & $1.63 \mathrm{a}$ & $1.60 \mathrm{~b}$ & $2.32 \mathrm{a}$ & $7.21 \mathrm{~b}$ \\
\hline $\mathrm{F}$ & $38.47^{* *}$ & $35.10^{* *}$ & $0.96^{\mathrm{ns}}$ & $1.71^{\mathrm{ns}}$ & $1.22^{\mathrm{ns}}$ & $3.18^{\mathrm{ns}}$ & $17.60^{* *}$ & $0.10^{\mathrm{ns}}$ & $9.38^{* *}$ \\
\hline \multicolumn{10}{|c|}{ Glyphosate Application-G } \\
\hline Without & $17.61 \mathrm{a}$ & $2.39 \mathrm{a}$ & $3.47 \mathrm{a}$ & $0.96 \mathrm{a}$ & $3.26 \mathrm{a}$ & $1.67 \mathrm{a}$ & $2.16 \mathrm{a}$ & $2.22 \mathrm{a}$ & $9.57 \mathrm{a}$ \\
\hline With & $15.23 \mathrm{a}$ & $2.53 \mathrm{a}$ & $3.74 \mathrm{a}$ & $0.98 \mathrm{a}$ & $3.61 \mathrm{a}$ & $1.88 \mathrm{a}$ & $1.70 \mathrm{~b}$ & $2.51 \mathrm{a}$ & $8.33 \mathrm{a}$ \\
\hline $\mathrm{F}$ & $2.53^{\mathrm{ns}}$ & $0.17^{\mathrm{ns}}$ & $0.23^{\mathrm{ns}}$ & $0.10^{\mathrm{ns}}$ & $1.20^{\mathrm{ns}}$ & $1.55^{\mathrm{ns}}$ & $8.63^{*}$ & $1.20^{\mathrm{ns}}$ & $1.18^{\mathrm{ns}}$ \\
\hline $\mathrm{F}: \mathrm{S} \times \mathrm{G}$ & $3.28^{*}$ & $0.65^{\mathrm{ns}}$ & $2.31^{\mathrm{ns}}$ & $0.68^{\mathrm{ns}}$ & $4.88^{*^{-}}$ & $3.17^{\mathrm{ns}}$ & $18.55^{* *}$ & $0.02^{\mathrm{ns}}$ & $9.22^{*}$ \\
\hline CV $(\%)$ & 18.24 & 26.35 & 31.01 & 16.03 & 18.56 & 18.59 & 16.43 & 22.07 & 25.45 \\
\hline LSD & 3.26 & 0.71 & 1.22 & 0.17 & 0.69 & 0.36 & 0.34 & 0.57 & 2.48 \\
\hline Standard Error & 1.06 & 0.23 & 0.39 & 0.05 & 0.22 & 0.12 & 0.11 & 0.18 & 0.80 \\
\hline
\end{tabular}

Note. AAS: amino acids; PROT: proteins; CLO: chlorophyll; L: leaves; R: roots; N: nodules. Stage-S: comparison between plant stages; Glyphosate Application-G: comparison between treatments that the plant received; F: $\mathrm{F}$ test; $\mathrm{F}=\mathrm{S} \times \mathrm{G}$ : test $\mathrm{F}$ of the stage unfolding analysis within each level of glyphosate; $\mathrm{CV}(\%)$ : Coefficient of variation. Different letters for the same organ indicates significantly statistics difference at $5 \%(*)$ and at $1 \%(* *)$ by Tukeys's test; $\mathrm{n}=16$; NS: Not significant at $5 \%$; (1) original data were transformed by $(\mathrm{x}+$ $0.5)^{1 / 2}$ before the statistical analysis.

According to the results (Table 1), the chlorophyll a content and total chlorophyll were significantly higher at the vegetative stage. There was a decrease in chlorophyll a content under glyphosate treatment (Table 1). We observed significant increase in total ureides and allantoin, in nodules, under glyphosate treatment (Table 2). The application of glyphosate did not adversely affect the concentration of ureides, allantoin and allantoic acid in the tissues of RR soybean, on the contrary, it was observed increase in total ureides and allantoin, in nodules, under glyphosate treatment (Table 2).

Table 2. Total ureides, allantoin and allantoic acid concentrations ( $\mu$ mols $\mathrm{g}^{-1} \mathrm{FW}$ ) in leaves, roots and nodules of RR soybean, cultivar BRS Valiosa, under glyphosate $\left(1.8 \mathrm{mg} \mathrm{plant}^{-1}\right)$ during vegetative and reproductive stages

\begin{tabular}{|c|c|c|c|c|c|c|c|c|c|}
\hline Treatments & URD-L & URD-R & URD-N & ALNT-F $^{(1)}$ & ALNT-R $^{(1)}$ & ALNT-N & ALA-F $\mathrm{F}^{(1)}$ & ALA-R ${ }^{(1)}$ & ALA-N \\
\hline \multicolumn{10}{|l|}{ Stage-S } \\
\hline Vegetative & $5.45 \mathrm{a}$ & $6.80 \mathrm{a}$ & $6.55 \mathrm{a}$ & $1.96 \mathrm{a}$ & $2.30 \mathrm{a}$ & $5.26 \mathrm{a}$ & $1.52 \mathrm{a}$ & $1.47 \mathrm{a}$ & $1.29 \mathrm{a}$ \\
\hline Reproductive & $5.29 \mathrm{a}$ & $6.10 \mathrm{a}$ & $5.88 \mathrm{a}$ & $2.12 \mathrm{a}$ & $2.12 \mathrm{a}$ & $4.76 \mathrm{a}$ & $1.26 \mathrm{a}$ & $1.47 \mathrm{a}$ & $1.12 \mathrm{a}$ \\
\hline $\mathrm{F}$ & $0.04^{\mathrm{ns}}$ & $0.72^{\mathrm{ns}}$ & $0.57^{\mathrm{ns}}$ & $0.81^{\mathrm{ns}}$ & $0.56^{\mathrm{ns}}$ & $0.42^{\mathrm{ns}}$ & $2.30^{\mathrm{ns}}$ & $0.00^{\mathrm{ns}}$ & $0.71^{\mathrm{ns}}$ \\
\hline \multicolumn{10}{|c|}{ Glyphosate Application- $G$} \\
\hline Without & $5.06 \mathrm{a}$ & $6.42 \mathrm{a}$ & $5.13 \mathrm{~b}$ & $1.94 \mathrm{a}$ & $2.22 \mathrm{a}$ & $4.01 \mathrm{~b}$ & $1.40 \mathrm{a}$ & $1.41 \mathrm{a}$ & $1.12 \mathrm{a}$ \\
\hline With & $5.68 \mathrm{a}$ & $6.47 \mathrm{a}$ & $7.30 \mathrm{a}$ & $2.14 \mathrm{a}$ & $2.20 \mathrm{a}$ & $6.02 \mathrm{a}$ & $1.38 \mathrm{a}$ & $1.54 \mathrm{a}$ & $1.28 \mathrm{a}$ \\
\hline $\mathrm{F}$ & $0.55^{\mathrm{ns}}$ & $0.00^{\mathrm{ns}}$ & $6.11^{*}$ & $1.09^{\mathrm{ns}}$ & $0.00^{\mathrm{ns}}$ & $6.86^{*}$ & $0.01^{\mathrm{ns}}$ & $0.38^{\mathrm{ns}}$ & $0.63^{\text {ns }}$ \\
\hline $\mathrm{F}: \mathrm{S} \times \mathrm{G}$ & $5.77^{\mathrm{ns}}$ & $4.60^{*}$ & $0.91^{\mathrm{ns}}$ & $3.97^{\mathrm{ns}}$ & $5.33^{*}$ & $1.01^{\mathrm{ns}}$ & $0.54^{\mathrm{ns}}$ & $0.99^{\text {ns }}$ & $0.11^{\mathrm{ns}}$ \\
\hline $\mathrm{CV}(\%)$ & 31.44 & 25.48 & 28.30 & 18.16 & 21.66 & 30.70 & 25.10 & 27.91 & 33.10 \\
\hline LSD & 1.84 & 1.79 & 1.91 & 0.40 & 0.52 & 1.68 & 0.38 & 0.45 & 0.43 \\
\hline Standard Error & 0.60 & 0.58 & 0.62 & 0.13 & 0.17 & 0.54 & 0.12 & 0.14 & 0.14 \\
\hline
\end{tabular}

Note. URD: ureides; ALNT: allantoin; ALA: allantoic acid; L: leaves; R: roots; N: nodules; Stage-S: comparison between plant stages; Glyphosate Application-G: comparison between treatments that the plant received; F: F test; $\mathrm{F}=\mathrm{S} \times \mathrm{G}$ : test $\mathrm{F}$ of the stage unfolding analysis within each level of glyphosate; CV (\%): Coefficient of variation. Different letters for the same organ indicates significantly statistics difference at $5 \%(*)$ and at $1 \%(* *)$ by Tukeys's test; $n=16$; NS: Not significant at $5 \%$; (1) original data were transformed by $(x+0.5)^{1 / 2}$ before the statistical analysis. 
There was greater accumulation of fresh mass in the vegetative stage, with a significant decrease in the reproductive stage (Table 3). Glyphosate treatment did not alter the fresh mass accumulation of nodules either the quantity of numbers (Table 3). In the vegetative stage, the activity of the enzymes, nitrogenase and allantoinase, was higher, with a significant reduction of nitrogenase activity, in the reproductive stage (Table 4). Nitrogenase activity was higher in the control treatment, whereas the activity of the enzyme allantoinase, in leaves, was higher in glyphosate treatment (Table 4).

Table 3. Nodules fresh weight (g) and number in RR soybean, cultivar BRS Valiosa under glyphosate (1.8 mg plant $^{-1}$ ) in vegetative and reproductive stages

\begin{tabular}{lll}
\hline Treatments & Nodule fresh weight & Nodule number \\
\hline Stages- $S$ & & \\
Vegetative & $1.66 \mathrm{a}$ & $113.33 \mathrm{a}$ \\
Reproductive & $1.01 \mathrm{~b}$ & $95.66 \mathrm{a}$ \\
F & $5.46^{*}$ & $0.86^{\mathrm{ns}}$ \\
\hline Glyphosate Application $-G$ & \\
Without & $1.38 \mathrm{a}$ & $89.16 \mathrm{a}$ \\
With & $1.28 \mathrm{a}$ & $119.83 \mathrm{a}$ \\
F & $0.13^{\text {ns }}$ & $2.59^{\text {ns }}$ \\
\hline F: S $\times \mathrm{G}$ & $1.85^{\mathrm{ns}}$ & $1.86^{\mathrm{ns}}$ \\
CV $(\%)$ & 36.29 & 31.57 \\
LSD & 0.91 & 43.91 \\
Standard Error & 0.20 & 13.47 \\
\hline
\end{tabular}

Note. Stage-S: comparison between plant stages; Glyphosate Application-G: comparison between treatments that the plant received; $\mathrm{F}$ : $\mathrm{F}$ test; $\mathrm{F}=\mathrm{S} \times \mathrm{G}$ : test $\mathrm{F}$ of the stage unfolding analysis within each level of glyphosate; $\mathrm{CV}$ $(\%)$ : Coefficient of variation. Different letters for the same organ indicates significantly statistics difference at $5 \%(*)$ and at $1 \%(* *)$ by Tukeys's test; $n=16$; NS: Not significant at $5 \%$; (1) Original data were transformed by $(\mathrm{x}+0.5)^{1 / 2}$ before the statistical analysis.

Table 4. Nitrogenase ( $\mu \mathrm{mol} \mathrm{H} \mathrm{H}^{-1} \mathrm{~h}^{-1}$ ) and allantoinase ( $\mu$ mol allantoic acid $\mathrm{g}^{-1} \mathrm{~h}^{-1}$ ) activities in leaves and roots of RR soybean, cultivar BRS Valiosa under glyphosate $\left(1.8 \mathrm{mg} \mathrm{plant}^{-1}\right)$ during vegetative and reproductive stages

\begin{tabular}{llll}
\hline Treatments & Nitrogenase & Allantoinase (Leaves) & Allantoinase (Roots) \\
\hline Stages- $S$ & & & \\
Vegetative & $4.78 \mathrm{a}$ & $0.29 \mathrm{a}$ & $0.08 \mathrm{a}$ \\
Reproductive & $2.62 \mathrm{~b}$ & $0.14 \mathrm{~b}$ & $0.05 \mathrm{~b}$ \\
$\mathrm{~F}$ & $10.86^{*}$ & $22.16^{* *}$ & $9.08^{*}$ \\
\hline Glyphosate Application $\mathrm{G}$ & & & \\
Without & $4.87 \mathrm{a}$ & $0.16 \mathrm{~b}$ & $0.07 \mathrm{a}$ \\
With & $2.54 \mathrm{~b}$ & $0.26 \mathrm{a}$ & $0.06 \mathrm{a}$ \\
F & $12.64^{*}$ & $9.53^{*}$ & $2.80^{\mathrm{ns}}$ \\
\hline $\mathrm{F}: \mathrm{S} \times \mathrm{G}$ & $1.27^{\mathrm{ns}}$ & $0.57^{\mathrm{ns}}$ & $11.21^{* *-\cdots}$ \\
CV $(\%)$ & 30.62 & 26.42 & 25.86 \\
LSD & 1.6 & 0.08 & 0.02 \\
Standard Error & 0.46 & 0.02 & 0.00 \\
\hline
\end{tabular}

Note. Stage-S: comparison between plant stages; Glyphosate Application-G: comparison between treatments that the plant received; F: F test; F $=\mathrm{S} \times \mathrm{G}$ : test $\mathrm{F}$ of the stage unfolding analysis within each level of glyphosate; $\mathrm{CV}$ $(\%)$ : Coefficient of variation. Different letters for the same organ indicates significantly statistics difference at $5 \%(*)$ and at $1 \%(* *)$ by Tukeys's test; $n=16$; NS: Not significant at $5 \%$; (1) Original data were transformed by $(\mathrm{x}+0.5)^{1 / 2}$ before the statistical analysis. 
Table 5. Interaction between developmental stages and treatments for amino acids (leaves), proteins (root), total and a chlorophyll (leaves), ureides (leaves) and allantoic acid (roots)

\begin{tabular}{|c|c|c|}
\hline \multirow{2}{*}{ Glyphosate } & \multicolumn{2}{|c|}{ Stages } \\
\hline & Vegetative & Reproductive \\
\hline \multicolumn{3}{|c|}{ Amino Acids-Leaves } \\
\hline Without & $8.43 \mathrm{~b} \mathrm{~B}$ & $22.03 \mathrm{a} \mathrm{A}$ \\
\hline With & 15.12 a B & $20.10 \mathrm{a} \mathrm{A}$ \\
\hline Standard Error & 1.50 & \\
\hline \multicolumn{3}{|l|}{ Proteins-Roots } \\
\hline Without & $3.79 \mathrm{a} \mathrm{A}$ & $3.44 \mathrm{a} \mathrm{A}$ \\
\hline With & $2.73 \mathrm{~b} \mathrm{~B}$ & $3.79 \mathrm{a} \mathrm{A}$ \\
\hline Standard Error & 0.32 & \\
\hline \multicolumn{3}{|l|}{ Chlorophyll a } \\
\hline Without & $2.83 \mathrm{a} \mathrm{A}$ & 1.49 a B \\
\hline With & $169 \mathrm{~b} \mathrm{~A}$ & $1.70 \mathrm{a} \mathrm{A}$ \\
\hline Standard Error & 0.16 & \\
\hline \multicolumn{3}{|c|}{ Total Chlorophyll } \\
\hline Without & $8.35 \mathrm{~b} \mathrm{~A}$ & 8.32 a A \\
\hline With & $13.05 \mathrm{a} \mathrm{A}$ & 6.10 a B \\
\hline Standard Error & 1.14 & \\
\hline \multicolumn{3}{|c|}{ Total Ureides-Roots } \\
\hline Without & $5.94 \mathrm{a} A$ & $7.00 \mathrm{a} A$ \\
\hline With & $7.65 \mathrm{a} \mathrm{A}$ & $5.19 \mathrm{a} \mathrm{A}$ \\
\hline Standard Error & 0.84 & \\
\hline \multicolumn{3}{|l|}{ Allantoin-Roots } \\
\hline Without & $2.01 \mathrm{a} \mathrm{A}$ & $2.39 \mathrm{a} \mathrm{A}$ \\
\hline With & $2.58 \mathrm{a} \mathrm{A}$ & $1.85 \mathrm{a} \mathrm{A}$ \\
\hline Standard Error & 0.24 & \\
\hline \multicolumn{3}{|c|}{ Allantoinase-Roots } \\
\hline Without & $0.11 \mathrm{a} \mathrm{A}$ & 0.04 a B \\
\hline With & $0.06 \mathrm{~b} \mathrm{~A}$ & $0.06 \mathrm{a} \mathrm{A}$ \\
\hline Standard Error & 0.01 & \\
\hline
\end{tabular}

Note. Upper cases compare between stages and lower cases compare stage along glyphosate application. Different letters indicate significantly statistical difference at $5 \%$ by Tukeys's test.

\section{Discussion}

There was a decrease in chlorophyll a content in glyphosate treatment, as reported by Zabiole et al. (2010), soybean resistant to glyphosate. Although chlorosis have not been observed, as well as yellowing signs on RR soybean leaves treated with glyphosate, Tuffi-Santos et al. (2008) reported chlorosis in plants of Eucalyptus urograndis, sprayed with glyphosate (172.8 and $\left.345.6 \mathrm{~g} \mathrm{ha}^{-1}\right)$, and necrosis and yellowing on Ricinus communis leaves by Sizenando-Filho et al. (2013).

Considering the formulations tested, by Tuffi-Santos et al. (2008), only Roundup transorb® leads to visual symptoms greater than $25 \%$ of total leaf area in all clones evaluated. Chlorosis observed in E. urograndis plants may have occurred due to chloroplast degeneration and/or inhibition of chlorophyll synthesis whose effects have already been observed in other species of plants exposed to glyphosate (Tuffi-Santos et al., 2008). In the interaction test (table 5), chlorophyll a content was higher in the vegetative stage without herbicide application, and for total chlorophyll the content was higher in the vegetative stage with glyphosate treatment.

Gordon (2007), reports that ureides represent the majority of the nitrogen transported in the sap xylem for the aerial portions of soybeans. Allantoin and allantoic acid are the two forms of ureides used for the transport of Nitrogen, mainly in species of the family Phaseoleae, so this class of metabolite, is often used to evaluate the biological efficiency of nitrogen fixation (Camargos et al., 2013). The main advantage for the transport of 
allantoin and allantoic acid is due to the transport efficiency of $\mathrm{N}$ relative to the $\mathrm{C}: \mathrm{N}$ ratio, which is $1: 1$, as reported by Camargos et al. (2013). The degradation of these ureides in the leaves and in the seed layer is catalyzed by an enzyme that has an absolute requirement of manganese-MN (Gordon, 2007).

Some changes may be related to the changes in transport and accumulation of these metabolites under some type of abiotic stress (Camargos et al., 2012), or may be indicative of adaptation/acclimation to stressful situations for BNF under exposure to nitrate, for example, as Canatto et al. (2013).

On the other hand, tissue Mn deficiency and drought stress may increase the concentration of ureides in the aerial part, signaling the symbiotic bacteria that stop with the biological fixation of nitrogen. In research done in Arkansas, it was found that foliar applications of Mn reduced ureides concentrations and prolonged nitrogen fixation in soybean (Gordon, 2007).

In the work described by Zablotowicz and Reddy (2007), using soybean plants, "Asgrow AG4702RR" cultivar (single and sequential applications of glyphosate), observed that all the evaluated plants were well nodulated, and that the total biomass of the nodule was not affected by herbicide application, corroborating with our study. Zablotowicz and Reddy (2007) also stated that the physiological responses and yield of soybean cultivars resistant to glyphosate may vary and depends on the geographical location, environmental conditions, soil types, and the sensitivity of native populations of nitrogen fixing bacteria.

Albrecht and Ávila (2010) confirmed that without the symbiosis there is decrease in nitrogen intake to the plant, consequently decreasing protein content. Considering it for soybean, which accumulate large amounts of proteins in their leaves and, afterwards, in grains, any disturb in $\mathrm{N}$ metabolism can lead to a low productivity. However, in our study we believe that this kind of response is unexpected since it was not observed decrease in nodule number or functioning, which is different from what was observed by Zablotowicz and Reddy (2007), and Ding et al. (2011).

Mazareli et al. (2013), state that a change in (total) nitrogen fixation activity may be directly related to the degree of nodulation but at the same time, related to nitrogen activity regardless of its effects on the degree of nodulation. One of the ways to evaluate an asymmetric nodule activity, a verification of a pattern of transported nitrogen compounds via xylem, for a transportation of ureides via xylem, are components directly associated with an $\mathrm{N}$-fixation.

King et al. (2011) concluded that it is not reasonable that glyphosate has any long time effect on BNF or in other critical process for yielding under experimental conditions. Bohm et al. (2009) also stated positive responses in BFN after glyphosate application. On the other hand, Bellaloui et al. (2006) reported decrease in nitrogenase activity when GR soybean (cultivar 'Delta Pine 4748S') plants were treated with glyphosate, corroborating with our results, although in interaction test there was no significant difference. This kind of results show that it is still not well settled a pattern of response and that variation occurs according to the cultivar and the rhizobium strain used as inoculator.

Some authors observed that glyphosate might affect nitrogen assimilation but not its fixation; this suggests that assimilation process may be more sensible during the early vegetative and reproductive stages because in these stages the $\mathrm{N}$ assimilation is higher (Bellaloui et al., 2008). By analyzing fixation capacity, we did not observe significant variations in response to glyphosate in factors interaction test, which is different from observation from Zabiole et al. (2010) that reports negative influence of glyphosate on BNF in glyphosate resistant soybean plants.

We observed that the fact of the nitrogenase enzyme activity was lower under treatment with glyphosate, does not imply a negative response to glyphosate seen that the fresh mass and the number of nodules did not significantly change as well as the concentration of compounds nitrogenous. In fact, the concentration of these compounds (ureides, allantoin and allantoic acid) in nodules increased with the glyphosate treatment. Therefore, treatment with glyphosate did not negatively affect the biological fixation of nitrogen, although the activity of the nitrogenase enzyme was lower.

Dvoranen et al. (2008), stated that herbicides such fluazifop-p-butyl and glyphosate have systemic action in plants; it means that when applied in aerial parts they can migrate to roots. These herbicides and their derivatives metabolites can interact with root symbionts. Jacques et al. (2010) reported that glyphosate lead to growth inhibition of Bradyrhizobium elkanni.

Santos et al. (2007), in an experiment whose treatments were composed by the application of three different formulations of glyphosate (Roundup Ready ${ }^{\circledR}$ and R.Transorb ${ }^{\circledR}$, both containing the isopropylamine salt, and Zapp $\mathrm{Qi}^{\circledR}$, formulated with potassium salt), were applied at the dose of $2000 \mathrm{~g} \mathrm{ha}^{-1}$ (commercial recommended 
dose) of the acid equivalent. It was applied in soybean plants (cultivar CD219RR) that is glyphosate tolerant due to the transgene CP4EPSPS. The author found that, in general, Roundup Transorb ${ }^{\circledR}$, formulated with Isopropylamine salt, has a greater negative effect on glyphosate tolerant soybean plants, because it was noted a considerable decrease in nodulation and additionally promoted negative effect on soil microorganism. Therefore, these results suggest that R. Transorb ${ }^{\circledR}$ stands out as the least suitable for application on glyphosate tolerant soybean plants.

The recommended glyphosate formulation for application in transgenic soybeans cultivars, despite the tendency to decrease productivity, showed grain yield similar to that of the control. It is possible that the greatest contribution to the decrease in soybean productivity caused by glyphosate formulations will be related to tissues injury, which is demonstrated by visual symptoms of plant toxicity, which may lead to disturbance in photo assimilates production (Santos et al., 2007).

Glyphosate application may impair nitrogen assimilation but it is not associated with losses in productivity

\section{Acknowledgements}

The authors are thankful for the financial support received by the Fundação de Amparo à Pesquisa do Estado de São Paulo (FAPESP-Brazil, grant $\mathrm{N}^{\circ}$. 2012/23266-3) and for the scholarship for scientific initiation (FAPESP-Brazil, grants $\mathrm{N}^{\mathrm{o}}$. 2012/16728-0-NCPB and 2012/16697-8-BGPC).

\section{References}

Albrecht, L. P., \& Ávila, M. R. (2010). Manejo de glyphosate em soja RR e a qualidade das sementes. Informativo ABRATES, 20, 45-54.

Bellaloui, N., Reddy, K. N., Zablotowicz, R. M., \& Mengistu, A. (2006). Simulated glyphosate drift influences nitrate assimilation and nitrogen fixation in non-glyphosate-resistant soybean. Journal of Agricultural and Food Chemistry, 54, 3357-3364. http://doi.org/10.1021/jf0531981

Bellaloui, N., Zablotowicz, R. M., Reddy, K. N., \& Abel, C. A. (2008). Nitrogen metabolism and seed composition as influenced by glyphosate application in glyphosate-resistant soybean. Journal of Agricultural and Food Chemistry, 56, 2765-2772. http://doi.org/10.1021/jf703615m

Bieleski, R. L., \& Turner, N. A. (1966). Separation and estimation of amino acids in crude plant extracts by thin-layer electrophoresis and chromatography. Analytical Biochemistry, 17, 278-293. https://doi.org/ 10.1016/0003-2697(66)90206-5

Bohm, G. M. B., Alves, B. J. R., Urquiaba, S., Boddey, R. M., Xavier, G. R., Hax, F., \& Rombaldi, C. V. (2009). Glyphosate- and imazethapyr-induced effects on yield, nodule mass and biological nitrogen fixation in field-grown glyphosate-resistant soybean. Soil Biology and Biochemistry, 41, 420-422. http://doi.org/ 10.1016/j.soilbio.2008.11.002

Camargos, L. S., Soares, C. R. S., Justino, G. C., \& Aguiar, L. F. (2013). Alocação de compostos nitrogenados de reserva durante a germinação de sementes de Canavalia brasiliensis. Biotemas, 26, 1-10. http://doi.org/ $10.5007 / 2175-7925.2013 \mathrm{v} 26 \mathrm{n} 4 \mathrm{p} 1$

Camargos, L. S., Souza, A. C., Souza, L. A., Justino, G. C., \& Aguiar, L. F. (2012). Calopogonium caeruleum apresenta baixa tolerância do sistema simbiótico à presença de nitrato. Acta Iguazu, 1, 9-16.

Canatto, R. A., Aguiar, L. F., Justino, G. C., Souza, L. A., \& Camargos, L. S. (2013). O nitrato influencia o metabolismo de compostos nitrogenados em calopogônio (Calopogonium mucunoides) ao longo do ciclo de vida. Biotemas, 27, 1-8. http://doi.org/10.5007/2175-7925.2014v27n1p1

Ding, W., Reddy, K. N., Zablotowicz, R. M., Bellaloui, N., \& Bruns, H. A. (2011). Physiological responses of glyphosate-resistant and glyphosate-sensitive soybean to aminomethylphosphonic acid, a metabolite of glyphosate. Chemosphere, 83, 593-598. http://doi.org/10.1016/j.chemosphere.2010.12.008

Dvoranen, E. C., Oliveira-Junior, R. S., Constantin, J., Cavalieri, S. D., \& Blainski, E. (2008). Nodulação e crescimento de variedades de soja RR sob aplicação de glyphosate, fluazifop-p-butyl e fomesafen. Planta Daninha, 26, 619-625. http://doi.org/10.1590/S0100-83582008000300018

Ferreira, T. C., Aguilar, J. V., Souza, L. A., Justino, G. C., Aguiar, L. F., \& Camargos, L. S. (2016). pH effects on nodulation and biological nitrogen fixation in Calopogonium mucunoides. Brazilian Journal of Botany, 39, 1015-1020. http://doi.org/10.1007/s40415-016-0300-0 
Gomes, M. A. F., \& Sodek, L. (1984). Allantoinase and asparaginase activities in maturing fruits of nodulated and non-nodulated soybeans. Physiologia Plantarum, 62, 105-109. https://doi.org/10.1111/j.1399-3054. 1984.tb05931.x

Gordon, B. (2007). Manganese nutrition of glyphosate-resistant and conventional soybeans. Better Crops Internacional, 91, 12-13.

Hinchee, M. A. W., Padgette, S. R., Kishore, G. M., Delannay, X., \& Fraley, R. T. (1993). Herbicide tolerant crops. In S. Kung \& R. Wu (Eds.), Transgenic plants (pp. 243-263). San Diego, Academic Press. https://doi.org/10.1016/B978-0-12-428781-5.50037-5

Hiscox, J. D., \& Israel-Stam, G. F. (1979). A method for the extraction of chlorophyll from leaf tissue without maceration. Canadian Journal of Botany, 57, 1332-1334. http://doi.org/10.1139/b79-163

Hoagland, D. R., \& Arnon, D. I. (1938). The water-culture method for growing plants without soil. Berkeley, University of California Agricultural Experimental Station.

Jacques, R. J. S., Procópio, S. O., Santos, J. B., Kasuya, M. C. M., \& Silva, A. A. (2010). Sensibilidade de estirpes de Bradyrhizobium ao glyphosate. Revista Ceres, 57, 28-33. http://doi.org/10.1590/S0034-737X 2010000100006

King, C. A., Purcell, L. C., \& Vories, E. D. (2001). Plant growth and nitrogenase activity of glyphosate-tolerant soybean in response to foliar glyphosate applications. Agronomy Journal, 93, 176-186. https://doi.org/ 10.2134/agronj2001.931179x

María, N., Becerril, J. M., Garcia-Plazaola, J. I., Hernández, A., Felipe, M. R., \& Fernández Pascual, M. (2006). New insights on glyphosate mode of action in nodular metabolism: Role of shikimate accumulation. Journal of Agricultural and Food Chemistry, 54, 2621-2628. http://doi.org/10.1021/jf058166c

Mazareli, R. C. S., Barros, P. C., Aguilar, J. V., Ferreira, T. C., \& Camargos, L. S. (2013). Caracterização inicial do metabolismo de nitrogênio em Alysicarpus vaginalis (L.) DC em resposta a presença de amônio. Acta Iguazu, 2, 38-48.

Padgette, S. R., Re, D. B., Barry, G. F., Eichholtz, D. E., Delannay, X., Fuchs, R. L., ... Fraley, R. T. (1995). New weed control opportunities: Development of glyphosate tolerant soybeans. In S. O. Duke (Ed.), Herbicide resistant crops (pp. 54-80). Boca Raton, CRC.

Santos, J. B., Ferreira, E. A., Reis, M. R., Silva, A. A., Fialho, C. M. T., \& Freita, M. A. M. (2007). Avaliação de formulações de glyphosate sobre soja roundup ready. Planta Daninha, 25, 165-171. http://doi.org/10.1590/ 0100-83582007000100018

Santos, J. B., Jacques, R. J. S., Procópio, S. O., Kasuya, M. C. M., Silva, A. A., \& Santos, E. A. (2004). Efeitos de diferentes formulações comerciais de glifosato sobre estirpes de Bradyrhizobium. Planta Daninha, 22, 293-299. http://doi.org/10.1590/S0100-83582004000200017

Sizenando-Filho, F. A., Almeida, E. I. B., Lucena, H. H., Sizenando, C. I. T., \& Pitombeira, J. B. (2013). Different doses and herbicides in relation to phenologycal development of castor tree. Tecnologia e Ciência Agropecuária, 7, 25-30.

Tuffi-Santos, L. D., Sant'Anna-Santos, B. F., Meira, R. M. S. A., Tiburcio, R. A. S., Ferreira, F. A., Melo, C. A. D., \& Silva, E. F. S. (2008). Visible and anatomic damages caused by glyphosate in Eucalyptus grandis leaves. Planta Daninha, 26, 9-16. http://doi.org/10.1590/S0100-83582008000100002

Zablotowicz, R. M., \& Reddy, K. N. (2007). Nitrogenase activity, nitrogen content, and yield responses to glyphosate in glyphosate-resistant soybean. Crop Protection, 26, 370-376. http://doi.org/10.1016/j.cropro. 2005.05.013

Zobiole, L. H. S., Oliveira-Junior, R. S., Kremer, R. J., Constantin, J., Yamada, T., Castro, C., ... Oliveira-Junior, A. (2010). Effect of glyphosate on symbiotic $\mathrm{N}_{2}$ fixation and nickel concentration in glyphosate-resistant soybeans. Applied Soil Ecology, 44, 176-180. http://doi.org/10.1016/j.apsoil.2009.12.003

\section{Copyrights}

Copyright for this article is retained by the author(s), with first publication rights granted to the journal.

This is an open-access article distributed under the terms and conditions of the Creative Commons Attribution license (http://creativecommons.org/licenses/by/4.0/). 